\title{
Beyond Equal Employment Opportunity Commission v. Associated Dry Goods Corp.: A New Defense of the EEOC's Role in the Title VII Enforcement Process
}

Under Title VII of the Civil Rights Act of $1964,{ }^{1}$ a person claiming to be injured as the result of discrimination in einployment may sue the offending employer or union in federal court. ${ }^{2}$ Before federal jurisdiction may be mvoked under this statute, ${ }^{3}$ however, an aggrieved party must file a written grievance (a charge) with the Equal Employment Opportunity Commission (EEOC), whereupon this Agency inust be given time to investigate the charge and to attempt to conciliate the parties. ${ }^{4}$ Title VII provides that charges are not to be made public; ${ }^{5}$ it also affords confidentiahity to anything said or done during conciliation negotiations ${ }^{6}$ and information obtained by it pursuant to its investigative authority.

1. 42 U.S.C. \& 2000e (1976).

2. Id. $\S 2000 \mathrm{e}-5(\mathrm{f})(3)$. Süch a suit is entitled to priority on the court calendar. $I d . \S 2000 \mathrm{e}-$ $5(f)(2),(5)(1976)$.

3. Other statutes may provide jurisdiction for employment discrimination suits. In Johnson v. Railway Express Agency, 421 U.S. 454, 461 (1975), such a suit was permitted under 42 U.S.C. $\S 1981$ (1976).

4. If the Commission determines, after investigating a charge, that there is not rcasonable cause to beheve it is true, it dismisses the charge; if it finds reasonable cause, it must endeavor to eliminate the allegedly unlawful employment practice through informal unethods of conciliation and persuasion. 42 U.S.C. $\S 2000 \mathrm{e}-5(\mathrm{~b})$ (1976). A cliarging party is allowed to sue upon receipt of a "right to sue" notice from the Commission, which unust issue either when the party's charge is dismissed or when 180 days have elapsed since the filing of the charge, id. $\$ 2000 \mathrm{e}-5(\mathrm{f})(1)$, with allowance being made for state and local agency proceedings. Id. $\$ 2000 \mathrm{e}-5(\mathrm{c})$, (d).

5. "Charges shall not be made public by the Commission." Id. $\$ 2000 \mathrm{e}-5(\mathrm{~b})$.

6. "Nothing said or done during and as a part of such [conciliation] endeavors unay be made public by the Commission, its officers or einployees, or used as evidence in a subsequent proceeding without the written consent of the persons concerncd." Id.

7. "It shall be unlawful for any officer or employee of the Commission to make public in any manner whatever any information obtamed by the Commission pursuant to its [investigative authority under this section] prior to the institution of any proceeding under this subchapter involving such information." Id. \&2000e-8(e).

This information is also exempt from compulsory disclosure under the Freedom of Information Act, 5 U.S.C. $\$ 552$ (1976), because investigative files are exempt froin the act's purview. Id. § 552(b)(3), (7); 29 C.F.R. § 1610.17 (1981). 
In EEOC v. Associated Dry Goods Corp. ${ }^{8}$ the Supreme Court upheld the EEOC's practice of allowing parties who have lodged grievances with the EEOC (charging parties) to examine information obtained by the Agency during the course of its imvestigation of their charges so that they may make an inforined decision on whether to file suit agaimst the party they have charged (the respondent). This Note will argue that the statute's text and legislative history point agamst upholding the disputed practice; the Court gave the statute a stramed reading im coming to its result. Moreover, even though the practice furthers the pohicy goals of Title VII, im part by helping the Agency to operate efficiently, this policy argument by itself cannot justify the Court's interpretation of the statute.

The Court's holding rested in part on the applicability of the "conteinporaneous construction" doctrine. The doctrime, which grants extreme deference to an interpretation of a statute made by the agency charged with its enforcement and issued contemporaneously with the statute's enactment, ${ }^{9}$ does encase policy goals in a doctrimal framework sufficient to justify a strained reading of a statute. There was no showing in this case, however, that the EEOC practice was adopted soon enough and used consistently enough to fall within the doctrine.

The instance of prehitigation disclosure of investigative inforination that was challenged and upheld in Associated Dry Goods occurred in 1974. In 1977, the EEOC im a major procedural overhaul decided to continue the practice im question and adopted many new practices. This Note proposes an extension to the contemporaneous construction doctrime which would grant deference to the EEOC's 1977 interpretation of Title VII to the same extent that the contemporaneous construction doctrime accords deference to initial agency interpretations. This proposed extension allows courts to give great weight to later agency constructions where there has been a failure of agency perforinance followed by a functionally successful agency overhaul. The EEOC's 1977 construction satisfies this requirement. Thus, althougl the Court reached the wrong result in Associated Dry Goods, such a result would be justified in a case arising today by the doctrinal extension proposed in this Note.

Part I of this Note presents the case. Part II explaims the case's effect on prior law. Part III argues that the Court's justifications for its result are not persuasive. Part IV then proposes an extension of the contemporaneous construction doctrime. Finally, Part V applies this doctrinal extension to justify the challenged EEOC practice and sug-

8. 449 U.S. 590 (1981) (5-2 decision).

9. Norwegian Nitrogen Prods. Co. v. United States, 288 U.S. 294, 315 (1933) (Cardozo, J.). 
gests a mode of analysis for courts 'considering future challenges to other EEOC praetices adopted in 1977.

\section{The CASE}

\section{A. The Facts}

Between 1971 and 1973, several employees filed employment discrimination charges agamst Joseph Horne Co., a division of Associated Dry Goods. ${ }^{10}$ In 1974, the EEOC requested inforination from Horne pursuant to its mvestigative authority under section 709(a) of Title VII. ${ }^{11}$ Horne refused to provide the information unless the EEOC would agree not to disclose it to the charging parties. Horne based its position on section 709(e) of Title VII, which prohibits the Commission from "mak[ing] public . . . any infornation" obtained pursuant to its investigative authority unless and until a lawsuit involvmg that information is filed. ${ }^{12}$ The EEOC refused to agree, explaining its practice of disclosimg information to a charging party contemplating suit against an employer. The EEOC then subpoenaed the material in October 1974. In June 1975, Horne sued to enjoin enforcement of the subpoena, argumg that the EEOC's practice violated Title VII. In 1978, the district court enforced the subpoena but prohibited the EEOC from disclosing any inforination so obtained to any charging party, declaring the EEOC's regulation authorizing disclosure to be invalid; ${ }^{13}$ the Fourth Circuit affirmed. ${ }^{14}$

10. The facts in this paragraph are taken from Associated Dry Goods, 449 U.S. at 593-95, and from Associated Dry Goods Corp. v. EEOC, 454 F. Supp. 387, 388-89 (E.D. Va. 1978), affd sub nom. EEOC v. Joseph Horne Co., 607 F.2d 1075 (4th Cir. 1979), rev'd sub nom. EEOC v. Associated Dry Goods Corp., 449 U.S. 590 (1981).

11. 42 U.S.C. $\$ 2000 \mathrm{e}-8(\mathrm{a})$ (1976).

12. Id. $\$ 2000 \mathrm{e}-8(\mathrm{e})$.

13. Associated Dry Goods Corp. v. EEOC, 454 F. Supp. at 394. The regulation in its entirely says:

Neither a charge, nor information obtained pursuant to section 709(a) of Title VIl, nor information obtained from records required to be kept or reports required to be filed pursuant to section 709 (c) and (d) of Title VII, shall be made matters of public information by the Commission prior to the institution of any proceedings under this Title involving such charge or information. This provision does not apply to such earlier disclosures to charging parties, or their attorneys, respondents or their attorneys, or witnesses where disclosure is deemed necessary for securing appropriate relief. This provision also does not apply to such earlier disclosures to representatives of interested Federal, State, and local authorities as may be appropriate or necessary to the carrying out of the Commission's function under Title VII, nor to the publication of data derived from such information in a form which does not reveal the identity of charging parties, respondents, or persons supplying the information.

29 C.F.R. \& 1601.22 (1981).

14. EEOC v. Joseph Horne Co., 607 F.2d 1075, 1078 (4th Cir. 1979), rev'd sub nom. EEOC v. Associated Dry Goods Corp., 449 U.S. 590 (1981). 


\section{B. The Opinions}

The Supreme Court reversed the Fourth Circuit. ${ }^{15}$ The Court sustained the EEOC's practice of disclosmg to a charging party information he needs to assess a potential lawsuit. The Court held that this practice does not violate Title VII's command in section 709(e) that the EEOC not make "public" prior to the commencement of a lawsuit any information obtained pursuant to its investigative authority. The Court then remanded the case to the district court for "proceedings consistent with this opinion,"16 allowing the EEOC both to enforce its subpoena and to retain the right to disclose information obtamed thereby to charging parties in accordance with its regular practice. ${ }^{17}$

Justice Stewart, writing for five of seven Justices, ${ }^{18}$ advanced six reasons for the Court's decision. The first two, based on statutory language and legislative history, looked to the statute's literal ineaning. The third, based on the contemporaneous construction doctrime, deferred to the EEOC's role in administering the statute. The last three, based on the practical effect of the EEOC's practice, looked to Title VII's policy goals.

First, the Court reasoned from the statute's text that the word "public" in section 709(e) of Title VII ${ }^{19}$ could not logically include charging parties. The court reasoned by analogy froin section 706(b), ${ }^{20}$ which prohibits disclosure of charges to the "public." Since it is illogical to prevent a charging party from seeing his own charge, "public" in section 706(b) does not include the charging party. Since "public" should mean the same thing in section $709(\mathrm{e})$ as in section 706(b), a charging party is not within the meaning of "public" in 709(e). ${ }^{21}$ Fur-

15. EEOC v. Associated Dry Goods Corp., 449 U.S. 590 (1981).

16. Id. at 604.

17. The Court did, however, restrict disclosure to material from the charging party's own charge file. The Court thus struck down some of the EEOC's "special disclosure rules," contained in \& 83.7(c) of the EEOC Compliance Manual, 1981 EEOC COMPL. MAN. (CCH) \& 83.7(c), which authorized limited disclosure of information from the files of other parties charging the same respondent. 449 U.S. at 603 . This invalidation of those special disclosure rules is part of the holding, since the issue before the Court was whether, or to what extent, Horne was properly demanding assurance of nondisclosure to "the charging parties" before complying with the subpoena. Id. at 593. Horne's demands included assurance that information revealed in investigating each of the charging parties' charges would not be disclosed to any other charging party. See Associated Dry Goods Corp. v. EEOC, 454 F. Supp. at 389-90.

The only problem with accepting the Court's ban on special disclosure as part of the holding is the label on Justice Stevens' opinion as "dissenting." 449 U.S. at 606. Justice Stevens surely agreed with this ban; querae why his opinion was not labeled "concurring in part and dissenting in part" as was that of Justice Blackmun.

18. Two Justices did not participate.

19. Section 709(e) of Title VII corresponds to 42 U.S.C. \& 2000e-8(e).

20. Section 706(b) corresponds to 42 U.S.C. $\$ 2000$ e-5(b).

21. 449 U.S. at 598. 
ther, another provision in section $706(\mathrm{~b})$, directing that nothing said or done in conciliation efforts "inay be made public . . . without the written consent of the persons concerned," reinforces the implication that "public" in that section does not include the parties. ${ }^{22}$

Second, the Court reasoned from legislative history that the word "public" did not include parties. Congress had indicated that the prohibition against disclosure was aimed at preventing "wide or unauthorized dissemination of unproved charges"; by implication, it did not apply to disclosure just to the parties. ${ }^{23}$ Further, Congress had indicated that some limited disclosure would be necessary for the EEOC to perform its function. Disclosure to parties, being sometimes "necessary," could not have been prohibited. ${ }^{24}$

As its third reason, the Court referred to the contemporaneous construction doctrine. ${ }^{25}$ This doctrine affords great weight to an interpretation of a statute issued conteinporaneously with its passage by the agency charged with its administration. ${ }^{26}$ The Court noted that the EEOC "first issued its rule permitting disclosure to the charging party shortly after Congress created the EEOC in 1965."27

The Court's fourth reason was that disclosure could speed investigation. The EEOC could streamline its investigative process if it could present parties "with specific facts for them to corroborate or rebut."28 A related fifth reason was that disclosure would aid settleinent attempts, since a party is far more likely to settle when he can intelligently assess the strengths and weaknesses of his case. Further, with disclosure, charging parties with poor cases would be dissuaded from filing frivolous lawsuits. ${ }^{29}$

The Court's sixth reason was grounded on the role of the private hitigant in the Title VII enforcement process. The Court observed that the private right of action has long been recognized as an integral part of the Title VII enforcement scheme. The private litigant, especially the poor one, could not play that role without information needed to assess the feasibility of litigation. ${ }^{30}$

22. Id. at $598 \mathrm{n} .13$.

23. Id. at 599 .

24. Id. at 599 (by implication).

25. Id. at 600 n.17.

26. Norwegian Nitrogen Prods. Co. v. United States, 288 U.S. 294, 315 (1933) (Cardozo, J.). Cardozo's language has been quoted and followed in Zenith Radio Corp. v. United States, 437 U.S. 443, 450 (1978); Udall v. Tallman, 380 U.S. 1, 16 (1965) (agency construed executive order); Power Reactor Dev. Co. v. International Union of Elec., Radio \& Mach. Workers, 367 U.S. 396, 408 (1961). See also infra note 130.

27. 449 U.S. at 600 n.17.

28. Id. at $600-01$.

29. Id. at 601 .

30. Id. at $601-03 \& \mathrm{n} .19$. 
Justice Stevens dissented, inaintaining that prelitigation disclosure violated the plain meaning of section 709(e) by effectively authorizing prehitigation discovery. ${ }^{31}$ In addition, he noted that Title VII provides criminal penalties for breach of its confidentiality provisions, but only if the breach is committed by an EEOC employee. ${ }^{32}$ Because Congress did not provide any penalties for parties who illegally disseminate information, Congress must not have intended that they have access to it. $^{33}$

Justice Blackmun filed a concurring and dissentimg opinion. $\mathrm{He}$ argued that Title VII permitted disclosure for the purpose of aiding EEOC's investigation but not for the purpose of assisting charging parties who are deciding whether to file suit. ${ }^{34}$

\section{II}

\section{IMPACT ON PRIOR LAW}

\section{A. Prior Law}

Before Associated Dry Goods, federal appeals courts had handed down apparently conflicting decisions on whether the confidentiality provision in section 709(e) bars disclosure to charging parties. One court had held that the EEOC conld disclose material to a party froin his own file for the purpose of letting him assess potential litigation. ${ }^{35}$ Two other circuits were faced with the slightly different issue of disclosure from "consolidated files"-files opened by the lodging of a broadbased Commissioner's Charge ${ }^{36}$ and filled with all individual charges filed against the same respondent. ${ }^{37}$ One court held that the EEOC could not disclose material froin a consolidated file to anyone outside the government; ${ }^{38}$ the other held that plamtiffs froin an uncertified class could see information from a consolidated file, but only if it was rele-

31. Id. at 606-07 (Stevens, J., dișsenting).

32. 42 U.S.C. $\$ 2000 \mathrm{e}-8$ (e) (1976).

33. 449 U.S. at $607 \&$ nn.3-4 (Stevens, J., dissenting). Currently, any person reqnesting investigative information froin the EEOC must execute a written agreeinent not to disclose it. 1981 EEOC COMPL. MAN. (CCH) § 83.3(b).

34. 449 U.S. at 604-06 (Blackmun, J., concurring and dissenting).

35. H. Kessler \& Co. v. EEOC, 472 F.2d 1147 (5th Cir.) (en banc), cert. denied, 412 U.S. 939 (1973).

36. A member of the Commission may also file a discrimination charge, either on behalf of particular individuals or, as here, independently. 42 U.S.C. $\$ 2000$ e-5(b) (1976).

37. The charges are consolidated so that one general investigation of the respondent can be held rather than holding one investigation for each charge. See 449 U.S. at 603. The file would presumably hold information obtained in investigating both the individual charges and the Coinmissioner's Charge. The prohibition against disclosure encompasses both types of information. See 42 U.S.C. \& 2000e-5(b), -8(a), -8(e) (1970).

38. Sears, Roebuck \& Co. v. EEOC, 581 F.2d 941 (D.C. Cir. 1978). 
vant to their own individual allegations of discrimination. ${ }^{39}$

The first case to consider the confidentiality problein was $H$. Kessler \& Co. v. EEOC, ${ }^{40}$ which arose as a subpoena challenge similar to that in Associated Dry Goods. In Kessler, the Fifth Circuit, en banc, held that Title VII does not prohibit disclosure of EEOC investigative information to the charging party or his attorney for the purpose of helping thein decide whether to sue and how to draft the complaint. The court observed that a typical charging party has enough trouble procuring counsel because of financial straits and treinendous time pressure, ${ }^{41}$ noted that the private litigant has an important role in enforcing Title VII, and concluded that he needs all the help he can get. ${ }^{42}$ The court next supported its result with legislative history, ${ }^{43}$ using the same argument that the Supreme Court would later nake in Associated Dry Goods. ${ }^{44}$ Finally, again anticipating the arguinent of the Supreme Court, ${ }^{45}$ the court pointed out two other phrases in the same act in which the word "public" did not include the parties. ${ }^{46}$

The next inajor decision was handed down by the District of Columbia Circuit in Sears, Roebuck \& Co. v. EEOC. ${ }^{47}$ In that case, the Commission filed a broad-based charge against Sears and thereby consolidated into one national file several liundred pending charges. After Sears provided information to the Agency, one charging party requested that the EEOC turn over information pertaining to her from the national file. Sears sued to enjoin the EEOC froin disclosing the information, and the court held that the information in the consolidated file was confidential with respect to everyone outside the governinent. ${ }^{48}$ It noted, first, that Title VII provides no effective ineans of preventing charging parties from publicizing information given to thein. ${ }^{49}$ It also reasoned that a contrary holding would undercut the congressionally preferred scheme of enforcement through conciliation

39. Burlington Northern, Inc. v. EEOC, 582 F.2d 1097 (7th Cir. 1978), cert. denied, 440 U.S. 930 (1979).

40. 472 F.2d 1147 (5th Cir.) (en banc), cert. denied, 412 U.S. 939 (1973).

41. Id at $1149-50$.

The court was applying pre-1972 law to the case, which gave a charging party only 30 days to file suit after receiving a right-to-sue letter. Civil Rights Act of 1964, Pub. L. No. 88-352, \& 706(e), 78 Stat. 259, 260. The 1972 ameudments exteuded this period to 90 days and lengthened several other limitations periods within Title VII. Equal Einploymeut Opportunity Act of 1972, Pub. L. No. 92-261, sec. 4(a), \& 706(e), (f)(1), 86 Stat. 103, 105-06.

42. 472 F.2d at 1149-50; see also id at 1151-52.

43. Id. at 1150 .

44. See supra text accompanying notes 23-24.

45. See supra text accompanying notes 19-21.

46. 472 F.2d at 1151.

47. 581 F.2d 941 (D.C. Cir. 1978).

48. Id at 947 .

49. Id at $946-47$. 
by injecting unnecessary adversariness into the agency/respondent relationship. ${ }^{50}$

Shortly after Sears, the Seventh Circuit decided Burlington Northern, Inc. v. EEOC. ${ }^{51}$ That case, like Sears, involved a consolidated investigative file which contained infornation supplied by the einployer in connection with both private charges and the Commission's charge. ${ }^{52}$ Two charging parties had filed a class action Title VII suit against Burlington on behalf of all black einployees, but the class had not yet been certified. ${ }^{53}$ As part of their pretrial discovery, these two parties subpoenaed the EEOC to produce the entire consolidated file. After the EEOC announced its intention to comply, Burlington agreed that the two parties could receive information relevant to their own allegations of discrimination but then sued to enjoin the EEOC froin coinplying with the subpoena to the extent that it permitted the charging parties to receive information concerning the factual circumstances surrounding any other party's charge.

The court first held that the charging parties were, for the purpose of section 709(e), neinbers of the public and subject to the ban on disclosure. $^{54}$ The court then held that, at least prior to class certification, any inforination not relevant to the nained plaintiffs' individual charges was not "involved" in a lawsuit within the language of section $709(\mathrm{e})^{55}$ and therefore could not be disclosed. ${ }^{56}$

Both the Sears and Burlington courts struggled with the question of what to do about Kessler, the only inajor case authorizing prelitigation disclosure. They atteinpted to distinguish Kessler on the ground that it involved a narrower issue-disclosure of the charging party's single charge, rather than disclosure from a national, consolidated file. Neither court was coinpletely convinced by this distinction, however, and they both ultimately disagreed with Kessler on the ground that the Kessler court had inadequately considered the innact its rule would have on the Title VII enforceinent scheme. ${ }^{57}$

Burlington set the stage for EEOC v. Joseph Horne Co.,$^{58}$ the lower

50. Id. at 946 .

51. 582 F.2d 1097 (7th Cir. 1978), cert. denied, 440 U.S. 930 (1979).

52. Id at 1098.

53. "As soon as practicable after the commencement of an action brought as a class action, the court shall determine by order whether it is to be so maintained." FED. R. CIV. P. 23(c)(1).

54. 582 F.2d at 1099-100.

55. Section 709(e) prohibits disclosure of "any information obtained by the Commission pursuant to its [investigative authority] prior to the institution of any proceedings under this title involving such information." 42 U.S.C. \$ 2000e-8(e) (1976).

56. 582 F.2d at 1101 .

57. Burlington, 582 F.2d at $1100-01 ;$ Sears, 582 F.2d at 947.

58. 607 F.2d 1075 (4th Cir. 1979), rev'd sub nom. EEOC v. Associated Dry Goods Corp., 449 U.S. 590 (1981). 
court version of Associated Dry Goods. There, a divided Fourth Circuit panel followed Sears and Burlington in a Kessler-type fact situation after opining that the three cases could not be distinguished. ${ }^{59}$

\section{B. Changes to Prior Law}

Associated Dry Goods clarifies the EEOC's right to disclose information to charging parties by holding that they are not inembers of the public with respect to material in their own file, exphicitly upholding $K_{e s s l e r}{ }^{60}$ and then going further by vahdating the EEOC's practice of disclosing information to parties filing on behalf of aggrieved individuals. ${ }^{61}$ The case does not, however, involve the issue of disclosure from consolidated files. Two separate consolidated file disclosure issues have appeared in the cases: first, disclosure to a party of material relevant to the party's own charge, disallowed in Sears and allowed without contest in Burlington; and second, disclosure to uncertified class plaintiffs of the factual circumstances surrounding the charges of other putative class members, disallowed in Burlington. Despite the fact that Associated Dry Goods did not concern a consohidated filc, ${ }^{62}$ the Court's reasoning implicitly upholds Burlington and partially overrules Sears.

Associated Dry Goods limited disclosure to the charging party to material in his own file. ${ }^{63}$ The Court noted in dicta, however, that the Commission often consolidates files for investigation and that, by chance of timing, generally rclevant information may appear first and fully in another party's file. ${ }^{64}$ The Court permitted the Commission to copy this type of information, such as statistics and other information about an employer's general practices, froin the consolidatcd file and include it in an individual charging party's file. ${ }^{65}$ To the extent that

\section{Id at 1077.}

60. 449 U.S. at 592 n.2.

61. See id. at 596-97; 1981 EEOC COMPL. MAN. (CCH) \& 83.5(c). Title VIl was amended in 1972 to allow the EEOC, as well as other individuals or organizations, to file charges on behalf of aggrieved parties. Equal Employment Opportunity Act of 1972, Pub. L. No. 92-261, sec. 4(a), $\$ 706(b), 86$ Stat. 103 (1972). This amendment was designed to enable aggrieved parties to have charges processed without coming forward publicly. 118 CoNo. REC. 4941 (1972) (section-bysection analysis of S. 2541, an earlier version of that act). The aggrieved party can thus avoid possible employer reprisals by keeping his identity secret. To deny him access to the file developed around his charge would penalize him for seeking to avoid employer reprisals. Such a penalty would be clearly contrary to congressional intent. Motorola, Inc. v. EEOC, 317 F. Supp. 282 (D. Ariz. 1968), remanded as prematurely decided, 460 F.2d 1245 (9th Cir. 1972).

62. 449 U.S. at 592 n.2. The Coart distinguished Sears and Burlington on that basis. Id.

63. Id. at 603.

64. Id. at 604 .

65. Id. at 603-04.

Such information might be indispensable to show that policies or practices neutral on their face are in fact discriminatory in operation, or that presumptively valid reasons given for a refusal 
Sears involved a charging party's right to see such generally relevant information, it is apparently overruled by Associated Dry Goods.

The Burlington uncertified class situation is different. There, plaintiffs from an uncertified class were seeking, inter alia, information about the factual circumstances of the charges of other potential class members. This is distmguishable froin Associated Dry Goods in two respects. First, Associated Dry Goods only permitted disclosure of information about an employer's general practices, which seeins not to include information about the factual circumstances of the charges of other individuals. Second, Associated Dry Goods is grounded on the principle that, regarding one party's charge, any other charging party is a member of the public to whom disclosure is forbidden. ${ }^{66}$ Thus, before class certification, other potential class meinbers are inembers of the public with regard to the uncertified class plaintiff, and the $A$ ssociated Dry Goods primciple requires that such factual information not be disclosed to the uncertified class plaintiff. ${ }^{67}$ For these two reasons, Associated Dry Goods should be understood to leave intact the holding in Burlington.

III

\section{ANALYSIS OF THE COURT'S REASONING}

The Court's reasoning is largely unpersuasive. Its arguments concerning the statute's literal meaning are weak. Its application of the contemporaneous construction doctrine is incorrect. Its policy arguments are generally sound as far as they go, but they alone cannot justify the Court's stramed interpretation of the statute.

\section{A. The Meaning of "Public"}

The Court's treatment of the disclosure issue starts with an analysis of the word "public" in section 709(e), which prohibits prelitigation public disclosure of information obtained pursuant to the EEOC's investigative authority. The Court's arguments that "public" excludes charging parties, which deal with both the statute's text and its legislative history, are outweighed by contrary arguments.

to hire, for example, were in fact a coverup for a discriminatory decision. See McDonnell Douglas Corp. v. Green, 411 U.S. 792, 805 (1973).

Technically, the Court has coine up with no statutory justification for this copying of relevant information from the consolidated file to the individual one. The deciding factor, lowever, is probably not the physical location of the information in the Commission's offices, but whether the same information could have beeu obtained, pursuant to the Commission's investigative authority, in investigating the individual charge.

66. 449 U.S. at 604.

67. After certification, the litigation would involve the claims of the unnamed class plaintiffs, so the prohibition in $\$ 709$ (e) would no longer apply. 42 U.S.C. \& 2000e-8(e) (1976). 


\section{The Statute's Text}

The Court first pointed out that a charging party is obviously entitled to see his own charge. ${ }^{68}$ Hence, section 706(b), which prohibits disclosure of charges to the "public," does not include charging parties, and, by analogy, neither does section 709(e). The argument, however, ignores the fact, pointed out by Justice Stevens, that there is no disclosure of information to one who already knows it. ${ }^{69}$ There is no need to consult the Title VII confidentiality rules if the only disclosure contemplated is that of a charge to the party who authored it, so this special case offers no useful analogy to section 709(e).

The Court next cited a phrase in section 706(b) barring public disclosure of conciliation efforts "without the written consent of the persons concerned."70 The Court understood this phrase, also, to suggest that the parties could not be part of the "public" since the parties are einpowered to release the information. ${ }^{71}$ However, the Court's interpretation is questionable. Just because the general rule against public disclosure does not apply where both parties give their consent, the general rule could logically apply against individual parties. This is especially true since the requirement of both parties' consent suggests that information is not to be disclosed against the wishes of either.

Finally, the statute's text contains a fairly strong indication that case files are not to be released to charging parties. As Justice Stevens mentioned in his dissent, Title VII provides criminal penalties for breach of its confidentiality provisions only for EEOC employees, suggesting that only they are authorized to see case files. ${ }^{72}$

\section{Legislative History}

To support its interpretation of "public" in section 706(e), the Court also considered legislative history. ${ }^{73}$ The weight of legislative history, however, does not support the Court's position. First, a statement by one of the bill's sponsors rehed on by the Court does not have the meaning the Court ascribed to it. Second, the role designed for the

68. 449 U.S. at 598.

69. Id. at 606 (Stevens, J., dissenting).

70. 42 U.S.C. $\$ 2000 \mathrm{e}-5(\mathrm{~b})$ (1976).

71. 449 U.S. at 598 n.13.

72. Id. at 606-07 (Stevens, J., dissenting).

73. The legislative history is somewhat unclear. One court found that the "committee reports and floor debates lend great comfort to both sides," Dent v. St. Louis-S.F. Ry., 406 F.2d 399, 403 (5th Cir.), cert. denied, 403 U.S. 912 (1969), probably because Title VII underwent extensive revisions culminating in a massive leadership compromise, and no cogent explanation of the policies underlying the compromises was ever offered. Johnson v. Seaboard Air Lime R.R., 405 F.2d 645, 649 \& n.7 (4th Cir. 1968), cert. denied, 394 U.S. 918 (1969); Commeut, Enforcement of Fair Employment Under the Civil Rights Act of 1964, 32 U. CHI. L. Rev. 430, 431-32 (1966). 
EEOC in the 1964 authorizing legislation suggests that Congress intended that charging parties be considered part of the public. Finally, the evidence does not suggest that Congress revised its view on this matter when it gave the EEOC greater enforceinent power in 1972.

The Court found support for its interpretation of "public" in an explanation of section 706(e) given by Senator Humphrey, one of the bill's sponsors:

[T] his is a ban on publicizing and not on such disclosure as is necessary to the carrying out of the Commission's duties under the statute. . . . The amendment is not intended to hamper Commission investigations or proper cooperation with other State and Federal agencies, but rather is aimed at the making available to the general public of unproven charges. ${ }^{74}$

The Court read this stateinent to suggest that section 706(e) barred disclosures to the general public but not to parties.

The thrust of Humphrey's remark, however, was the narrower distinction that disclosure "necessary to the carrying out of the Commission's duties" would be permitted. In two sentences omitted by the Court in the quotation set out above, Humphrey gave examples of such necessary disclosure: "Obviously, the proper conduct of an investigation would ordinarily require that the witnesses be informed that a charge had been filed and often that certain evidence had been received. Such disclosure would be proper."75 This exainple is a far cry froin disclosure to parties who are trying to assess the feasibility of litigation. Some disclosure to witnesses is necessary for the Commission to carry on an investigation. In contrast, although disclosure to charging parties would be of considerable help in speeding the investigation along, ${ }^{76}$ it is not evident that such disclosure is "necessary" in the saine, narrow sense. In sum, Humphrey's remark focuses on the allowance of necessary disclosures, but it does not conteinplate disclosure to parties for the purpose of helping them decide whether to file suit. ${ }^{77}$

Even if Senator Humphrey's statement could be read in support of the Court's interpretation, the general legislative history of Title VII

74. 449 U.S. at 599 (emphasis and ellipsis in original) (quoting 110 CoNG. REC. 12,723 (1964)). For the omitted language, see infra text accompanying note 75.

75. 110 CONG. REC. 12,723 (1964) (remarks of Sen. Humphrey). Apparently Humphrey meant that merely asking witnesses certain questions would reveal to thein certain basic information.

76. See infra text accompanying notes 185-94.

77. In any event, Humphrey's language does not deserve microscopic dissection because his statenent was geuerally imprecise. He said that the prohibition was aimed at the making available to the general public of "unproven charges," while in fact the prohibition covers not only charges but "any information obtained by the Commission pursuant to its [investigative] authority." 42 U.S.C. $\$ 2000 \mathrm{e}-8$ (e) (1976). Charges are only a sinall portion of such information, and they contain no sensitive employer data. 
shows that Congress did not intend to permit disclosure to parties. Congress created by design a tame EEOC, because it did not trust the EEOC to be impartial. In the 1964 legislation establishing the EEOC, Congress denied the Commission the power held by its then existing state counterparts to issue cease-and-desist orders. ${ }^{78}$ The House, in replacing a proposed cease-and-desist power with the less potent power to sue in federal district court ${ }^{79}$ favored court trials over administrative proceedings because they provided a "fairer forum [for an employer] to establish innocence." 80 The Senate, in stripping away even the power to sue, ${ }^{81}$ apparently feared that even as a litigator the EEOC would be too overbearing. The Senate sentiments prevailed, for its version becaine law. ${ }^{82}$ Since Congress feared that the EEOC would be too powerful

78. On the state laws generally, see Kovarsky, A Review of State FEPC Laws, 9 LAB. L.J. 478, 478-81 (1958); Annot., 44 A.L.R.2d 1138 (1955). State agencies processed complaimts through several stages, as necessary: investigation, reasonable cause determination, conciliation and persuasion, public hearing, and finally a cease-and-desist order enforceable in the courts. Note, The Operation of State Fair Employment Practices Commissions, 68 HARv. L. REv. 685, 686 (1955). State agencies seldom initiated enforceinent proceedings, especially during their first few years, for fear that einployers would become alienated, thereby making elimination of discriminatory practices more difficult. Id. at 693.

79. Two earher bills would have given the EEOC cease-and-desist power: the substitute bill prepared by Subcommittee No. 5 of the House Judiciary Committee for H.R. 7152 (the bill which eventually became the Civil Rights Act of 1964), and H.R. 405, the so-called FEPC bill. See H.R. REP. No. 914, 88th Cong., 1st Sess. 45 (additional views of Rep. Meader), reprinted in 1964 U.S. CODE CONG. \& AD. News 2391, 2414, and in EEOC, Legislative History OF TitLES V11 AND XI of Crvil Rights ACT of 1964, at 2001, 2045 (1968). The House floor version of Title VII replaced the EEOC's cease-and-desist power with the lesser power to sue in federal court. See id. at 28-29. The Senate substituted a bill, sponsored by Senators Humphrey and Dirksen, which later passed the House without amendinent, 110 CoNG. REc. 12,819 (1964), and bccame law. That bill demied the EEOC even the power to sue in district court; the responsibility of bringing "pattern or practice" § 707 suits was assigned to the Attorney General. Civil Rights Act of 1964, Pub. L. No. 88-352, §§ 706(e), 707(a), 78 Stat. 241, 260-61 (1964).

80. H.R. REP. No. 914, supra note 79, pt. 2, at 29 (additional views of Reps. McCulloch, Lindsay, Shriver, MacGregor, Mathias, and Bromwell).

81. See supra note 79 .

82. Id.

The Senate bill first included the confidentiality provision of $\S 706(e)$. The House bill had incorporated by reference section 10 of the Federal Trade Commission Act, 15 U.S.C. $\$ 50$ (1976), which prohibits agency einployees from "inak[img] public any information obtained by the Coinmission without its authority." See H.R. 7152, 88th Cong., 1st Sess. \$ 710(a) (1963), reprinted in H.R. REP. No. 914, supra note 79, at 1, 13-14. At that time, FTC regulations construing section 10 did not prohibit disclosure to parties to the FTC proceedings. See 16 C.F.R. $\$ \$ 1.41, .133, .134$ (1964) (current version at 16 C.F.R. $\$ \S 3.36,4.10$ (c) (1981)). The Senate substitute bill, on the other hand, was inuch more specific and forceful, providing that agency employees must not "make public in any manner whatever" any investigative inforination prior to the filing of a lawsuit. Civil Rights Act of 1964, Pub. L. No. 88-352, \& 709(e), 78 Stat. 241, 264.

The Court in Associated Dry Goods asserted that the House inay well have assumed that the Senate's disclosure provisions were not more restrictive than the House's when it passed the Senate bill without amendment. 449 U.S. at 599 n.15. The inore plausible conclusion, however, is that the House capitulated for the sake of getting the bill on the President's desk. The bill had already weathered one filibuster in the Senate. See 110 CoNG. REC. 13,327 (1964) (cloture agreed to). In any case, its failure to amend the confidentiality provisions in 1972 , see infra note 87 , is an 
and partial a litigator, it probably did not intend to permit the EEOC to weiglit litigation in favor of employees by allowing the EEOC investigators to collect information from the respondent and then liand the information over to the respondent's potential adversaries.

When Congress amended Title VII in 1972 to give the EEOC power to sue in federal district court, it is unlikely that Congress intended to change its position on prelitigation disclosure to parties. Congress was dissatisfied with an ineffective EEOC, and it felt a need to grant it more power. ${ }^{83}$ At the saine time, however, voluntary conciliation was still to be the primary enforcement inechamism. ${ }^{84}$ In both houses of Congress, committees favorably reported bills granting ceaseand-desist authority, but persistent opposition on the fioor replaced this authority with the lesser power to file suit in federal court. In declining to grant cease-and-desist power, Congress expressed concern that the EEOC should conciliate rather than advocate civil rights. ${ }^{85}$ Congress also expressed fear that an active enforcement stance would jeopardize the EEOC's "quasi-judicial neutrality." 86

Thus, although the EEOC was given more enforcement power by the Equal Employment Opportunity Act of 1972, it is unlikely that in the process Congress intended to change its 1964 stance forbidding prelitigation disclosure to charging parties. Rather, it probably just wanted to keep the status quo, allowing disclosure to witnesses but not to charging parties. ${ }^{87}$ In sun, the legislative history froin both 1964

imdication that the House has not found fault with the Senate language. See Zemel v. Rusk, 381 U.S. 1, 11-12 (1965).

83. See Occidental Life Ins. Co. v. EEOC, 432 U.S. 355, 361-64 (1977).

84. See Alexander v. Gardner-Denver Co., 415 U.S. 36, 44 (1973); 118 CoNG. REc. 7168, 7565-66 (1972) (section-by-section analysis of the Conference Committee bill). Although two authorities have urged that the Equal Employment Opportunity Act of 1972 was enacted because of congressional discontent with the voluntary approach in general, EEOC v. Joseph Horne Co., 607 F.2d at 1079-80 (concurring and dissenting opinion); Comment, The Meaning of "Publie" in Section 709(e) of the 1964 Civil Rights Act and Access to Information Gathered by the EEOC, $67 \mathrm{KY}$. L.J. 430, 435 (1978-79), both based their conclusion on a passage in the committee report accompanying H.R. 1746 which argued in favor of cease-and-desist authority. H.R. REP. No. 238, 92d Cong., Ist Sess. 9 (1972), reprinted in 1972 U.S. CODE CONG. \& AD. News 2137, 2144. Another section of the same report discussing the general need for the bill niay have been more unbiased: "An examination of the statistics. . . clearly shows that the voluntary approach currently applied has failed to eliminate employment discrimination." Id. at 3 (emphasis added). Another factor that could have accounted for these statistics is the reluctance of individuals fearful of possible physical or economic reprisals to sue their einployer or union. Congress may have thought so too, as the 1972 amendments allowed organizations or even the Commission itself to file charges on behalf of aggrieved parties. Equal Employment Opportunity Act of 1972, Pub. L. No. 92-261, sec. 4(a), § 706(b), 86 Stat. 103, 104.

85. 118 CONG. REC. 933 (1972) (remarks of Sen. Thurmond); see also id. at 931-32, 943-44 (remarks of Sens. Allen and Talmadge).

86. H.R. REP. No. 238, supra note 84, at 62 (Minority Views on H.R. 1746).

87. An intent to keep the status quo may explain why the conference committee deleted without explanation new language in the Senate version forbidding prebitigation disclosure to any- 
and 1972 does not support the Court's view that charging parties are not members of the "public."

\section{B. The Contemporaneous Construction Doctrine}

The Court also supported its holding by invoking the contemporaneous construction doctrine. Associated Dry Goods did not demonstrate, however, that the EEOC practice in question fell within the scope of this doctrine.

The contemporaneous construction doctrine is a justification for extreme deference to an action by an administrative agency under color of its authorizing statute. Although the interpretation of a statute by an agency charged with its enforceinent is entitled to soine deference, ${ }^{88}$ that deference is usually limited by the court's obligation to uphold the clear meaning of a statute, as revealed by its language, purpose, and history. ${ }^{89}$ According to the doctrine, the construction by an agency made contemporaneously with a statute's enactment is entitled to a particularly great deference, especially if the construction has been consistent over a long period of time. ${ }^{90}$ It too must fall, however, in the face of compelling indications that it is erroneous. ${ }^{91}$ There is thus a zone of statutory interpretation-perhaps best described as "strained but not impossible" - which cannot be justified by ordinary deference to administrative expertise but can be justified by the contemporaneous construction doctrine. Part $\mathrm{A}$ above and Part $\mathrm{C}$ below show that the Court's interpretation of section 709(e) can be characterized as strained but not impossible. Therefore, the contemporaneous construction doctrine, if applicable, might justify the Court's interpretation.

The Court cited the EEOC's original regulation regarding disclosure, promulgated on July 1, 1965, as a conteinporaneous construction entitled to deference. ${ }^{92}$ That regulation permits prelitigation disclosures to the charging party "as may be necessary or appropriate to the carrying out of the Cominission's functions."93 The language, however, does not clearly support prelitigation disclosure for the purpose of aiding a charging party in deciding whether to sue. In fact, insofar as its wording closely reseinbles that of Senator Huinphrey's explanation, the regulation may have been ineant to permit only disclosures neces-

oue outside the government. This language was contained in S. 2515, 92d Cong., 1st Sess. sec. 6(b), \& 709(e), 118 CoNG. REC. 289, 292 (1972); see also 118 CoNG. Rec. 4943 (1972).

88. Griggs v. Duke Power Co., 401 U.S. 424, 433-34 (1971).

89. Southeastern Community College v. Davis, 442 U.S. 397, 411 (1979); Espinoza v. Farah Mfg. Co., 414 U.S. 86, 94-95 (1973) (Title VII case).

90. See supra note 26 and infra note 130.

91. E.I. du Pont de Nemours \& Co. v. Collins, 432 U.S. 46, 54-55 (1977).

92. 449 U.S. at 600 n.17 (citing 30 Fed. Reg. 8407 (1965)).

93. 29 C.F.R. $\& 1601.20$ (1966). 
sary in a narrow, inechanical sense for the Commission to function. ${ }^{94}$

The EEOC's contemporaneous construction is clarified slightly by a statement in its first annual report saying that in practice it allowed disclosure of "any relevant information" to the charging party. ${ }^{95}$ However, the next sentence in tlie EEOC's stateinent, mentioning the information a charging party's attorney is entitled to receive, is probably describing the information the Agency considered relevant: case status, correspondence, and conciliation offers. ${ }^{96}$ This is not the type of information a cliarging party typically seeks in deciding wlietlier to sue. Case status would have limited utility in the courtroom, and conciliation offers cannot be used as evidence because of section $706(\mathrm{~b}){ }^{97}$ Correspondence may or may not contain pertinent factual information which the charging party does not already know; in most cases, it probably would not. ${ }^{98}$ In contrast, investigative reports are likely to contain useful factual information which a charging party would seek in trying to decide whether to sue. But the annual report does not mention disclosure of investigative reports. Therefore, tlie EEOC's statement in its first annual report does not demonstrate that the EEOC's asserted construction was contemporaneous.

In sum, the evidence advanced does not sliow that the EEOC's practice of disclosing information to parties for the purpose of letting them assess potential litigation was adopted contemporaneously witl the EEOC's creation and followed since, as required by the contemporaneous construction doctrine. If that had been the practice, the EEOC likely would have done inore than merely point to the vague regulation cited above and assert that it "has not varied from that contemporaneous construction of its statute." 99

94. See supra notes 74-77 and accompanying text. Justice Blackmun also read the regulation this way:

Because the Commission must communicate charges to respondents, investigate the charges that have been filed, determine whether there is reasonable cause to believe that the charges are true, inform the parties of its determination, and atteinpt to settle charges ... there undoubtedly are many occasions when it must disclose solne of its information to parties and to witnesses.

449 U.S. at 605 (Blackmun, J., concurring in part and dissenting im part). As support for this reading of the regulation, Justice Blackmun pointed out that the regulation was changed in 1977 to permit disclosure to a charging party "deemed necessary for securing appropriate relief." 449 U.S. at 605 n.* (quoting 29 C.F.R. \& 1601.22 (1979)). If the earlier regulation had encompassed disclosures such as those in Associated Dry Goods, there would have been hittle reason to change the wording.

95. EEOC, First ANNUAL RePORT 52 (1967).

96. Id.

97. Sce supra note 6 for the pertinent text of this section. Another part of $\S 706(\mathrm{~b})$ deals with the disclosure of charges. See supra note 5 .

98. The notable exception is the reasonable cause determination. See 1981 EEOC CoMPL. MAN. (CCH) \& 40.7 .

99. Brief for Petitioner at 25, Associated Dry Goods. See also id. at 8 \& nn.3-4. 


\section{Policy: Effectuating Title VII's Goals}

The Court also found support for its holding in policy considerations. This Section analyzes the pohcy arguments made for and agamst prehitigation disclosure to charging parties, including soine not considered by the Court, and agrees with the Court that the policy arguments weigh in favor of such disclosure. As Part IV, Section A demonstrates, however, policy arguinents are not sufficient to justify a strained construction of a statute, ${ }^{100}$ at least not without a special doctrinal exception that justifies doing so. ${ }^{101}$

The first policy arguinents advanced by the Court are that prelitigation disclosure of investigative infornation could speed investigation and encourage settlement atteinpts. ${ }^{102}$ Part $\mathrm{V}$ of this Note shows that the Court is apparently correct.

The Court also observed that the "private right of action" is an important part of the Title VII enforcement scheme. ${ }^{103}$ If anything, the Court understated this point. Given the EEOC's hinited resources, legal action taken against respondents is parallel in importance to suits filed by the EEOC. ${ }^{104}$

The evidence indicated that not enough legal action was taken against respondents; ${ }^{105}$ some respondents viewed the threat of Title VII litigation as nonexistent. ${ }^{106}$ This condition could very well have been caused by lack of disclosure, smce most complainants do not have sufficient information to persuade private attorneys to take their cases. Without a reasonable assurance of success, most private attorneys will not take Title VII cases on a contingent fee basis, ${ }^{107}$ and only the rare complainant has adequate resources to hire an attorney to file a Title VII action. ${ }^{108}$ Under these circumstances, the private right of action was not fulfilling its role in the Title VII enforcement scheme.

100. See infra notes 124,126 and accompanying text.

101. See infra Part IV, Sections B and C.

102. See supra text at notes 28-29.

103. 449 U.S. at $602 \& \mathrm{n} .21$.

Charging parties can sue under 42 U.S.C. \& 1981. Johnson v. Railway Express Agency, 421 U.S. 454, 461 (1975). Alternatively, they can demand a right-to-sue letter from the EEOC after 180 days have elapsed from the filing of their charges. 42 U.S.C. $\$ 2000 \mathrm{e}-5(\mathrm{f})(1)(1976)$.

104. Alexander v. Gardner-Denver Co., 415 U.S. 36, 45 (1974).

105. Staff of House Comm. on Education and Labor, 94th Cong., 2d Sess., Staff REPORT ON OVERSIOHT INVESTIOATION OF FEDERAL ENFORCEMENT OF EQUAL EMPLOYMENT OpPoRtunity LAws 34 (Comm. Print 1976) [heremafter cited as 1976 Oversight REPORT].

106. B. WOLKINSON, BLACKS, UNIONS, AND THE EEOC 101 (1973).

107. H. Kessler \& Co. v. EEOC, 472 F.2d 1147, 1152 (5th Cir.), cert. denied, 412 U.S. 939 (1973); 5 U.S. COMM'N ON CIVIL RIGHTS, THE FEDERAL CIVIL RIOHTS ENFORCEMENT EFFORT1974, at 519-20 (1974) [hereimafter cited as Volume V].

108. B. Wolkinson, supra note 106, at 130; see also U.S. COMM'N ON Clvil Riohts, THE FEDERAL CiviL RIOHTS ENFORCEMENT EFFoRT-1977, at 219-20 (1977) [heremafter cited as 1977 CIVIL RIOHTS REPORT]. 
The Court responded to the argument that such disclosure would lead to a flood of litigation by noting that disclosure would not necessarily have the effect of stimulating litigation. With the relevant information known to both parties, they might find it more prudent to settle. Furthermore, disclosure might discourage frivolous suits or those based on misconceptions. ${ }^{109}$ Finally, even if disclosure did lead to a significant increase in litigation, such suits are a necessary part of Title VII enforcement. ${ }^{110}$

Another policy challenge to the EEOC's prelitigation disclosure rules is the argument that respondents would not cooperate with the EEOC if they knew that the Agency would turn factual information over to charging parties. ${ }^{11}$ As a result, the EEOC's effectiveness as a conciliator would be impaired and charging parties would be unable to obtain relief quickly. In practice, however, it is questionable whether nost einployers would cooperate with the EEOC anyway. Many respondents view the EEOC as a civil rights advocate rather than a neutral investigating body; ${ }^{112}$ in the alternative, they view the EEOC as a threat because they fear the costliness of consent decrees and settlement payments. ${ }^{113}$ Furthermore, even if the Agency did not release information to charging parties, respondents would still be reluctant to give it much aid; after all, the Agency does have authority to institute "pattern-and-practice" Title VII suits ${ }^{114}$ which are not limited by the allegations in the charges it is investigating. ${ }^{115}$ Hence, the threat of a "chilling effect" on the EEOC's investigative ability presented by prelitigation disclosure is more imaginary than real. ${ }^{116}$

109. 449 U.S. at 601-02. In 1977, the EEOC estimated that about $20 \%$ of all charges filed were either incomplete, frivolous, or outside the EEOC's jurisdiction. 1977 CIVIL RIGHTS REPORT, supra note 108, at 215 . When it actually placed professionals in the intake process to weed out such charges, a 31\% reduction in intake resulted. See infra text accoinpanying note 192.

110. 449 U.S. at 602.

111. For example, Sears apparently would not have cooperated with the EEOC if it knew that factual data it provided would be disclosed to charging parties. Sears, Roebuck \& Co. v. EEOC, 582 F.2d 941,944 (D.C. Cir. 1978).

112. 1977 CIVIL Rights REPORT, supra note 108, at 224.

113. Alexander, Inside the Equal Employment Opportunity Commission (May 21, 1976) (speech before the Equal Employment Clinic at Howard University School of Law), reprinted in StafF of Senate Comm. on the Judiciary, 94th Cong., 2D Sess., Civil Rights 61, 65 (Comm. Print 1976).

114. 42 U.S.C. $\$ \S 2000 e-5(f)(1),-6(1976)$.

115. EEOC v. Hearst Corp., 553 F.2d 579, 580-81 (9th Cir. 1977); EEOC v. General Elec. Co., 532 F.2d 359, 366-70 (4th Cir. 1976) (EEOC is allowed to file suit which is broader in scope than the charge filed with it, even if evidence pointing to the violations not covered by the original charge was obtained through investigation of that charge).

116. It can also be argued that, since all factual information is available for discovery once litigation starts, see 42 U.S.C. $\$ 2000$ e-8(e) (1976), a respondent has no real reason to oppose prelitigation disclosure. However, in practical terms prehtigation disclosure is indispensable to a charging party trying to persuade an attorney to take the case. See supra text accompanying notes 107-08. 
Finally, a policy objection to the disclosure can be grounded on equitable considerations. Given that the EEOC is supposed to be a neutral quasi-judicial body, ${ }^{117}$ it may be unfair to allow the Agency to take the most intimate details of its conversations with respondents expecting administrative impartiahty and hand them over to complainants. It is arguably just as unfair, however, to ask a charging party to settle his claim by "conciliation" when he has no access to information he needs to assess the strengths and weaknesses of his case. ${ }^{118}$

Thus, the policy arguments on balance support the result in Associated Dry Goods. But policy arguinents, by themselves, are not enough to justify a stramed construction of a statute. ${ }^{119}$ Sections A and B of Part III showed that neither legislative history nor the contemporaneous construction doctrine support the Court's exclusion of charging parties from the "public" in section 709(e). It follows that the Court was wrong to permit prelitigation disclosure to charging parties.

IV

\section{A Proposed Extension of the Contemporaneous CONSTRUCTION DOCTRINE}

Under the analysis set out in Part III, Associated Dry Goods was wrongly decided. Part IV proposes a statutory interpretation doctrime which, given the 1977 procedural overhaul of the EEOC, would justify the disputed disclosure practice in litigation arismg today. ${ }^{120}$ The proposal extends the conteinporaneous construction doctrine to constructions that are a part of a major procedural reforn of a heretofore poorly functioning agency. This doctrime can be termed the neocontemporaneous construction doctrine. Since this doctrine is policybased, Section A considers the role of pohcy considerations in statutory interpretation. Section B lays further groundwork by discussing the contemporaneous construction doctrime. Section $\mathrm{C}$ sets out the elements of the neocontemporaneous construction doctrime and discusses reasons for and possible objections to its use.

117. 1977 CIVIL Rights RePORT, supra note 108, at 224-25; see supra note 86 and accompanying text.

118. Associated Dry Goods, 449 U.S. at 601 \& n.18. A settlement negotiation is, after all, "a bargaining process, with give and take, and stress upon and use of the strengths of one's own position and the weaknesses of the position of the other party." Renegotiation Bd. v. Bannercraft Clothing Co., 415 U.S. 1, 21-22 (1974).

119. See infra notes 124,126 and accompanying text.

120. Though the EEOC's subpoena enforcement action began before its 1977 procedural overhaul, the trial court, circuit court, and Supreme Court rulings came down afterward. See supra notes 10-15 and accompanying text. This timing tnakes it difficult to say what these courts "should have" done if the Court had recognized the neocontemporaneous construction doctrine that is proposed in Section C of this Part. 


\section{A. The Role of Policy in Statutory Interpretation}

Statutory interpretation is the process of giving effect to a legislative purpose. ${ }^{121}$ Courts look to three sources of information in interpreting statutes: statutory language, legislative history, and policy. ${ }^{122}$ When the statutory language is clear, courts generally give effect to the language and do not consider the other factors. If the statutory language is ambiguous, courts look to legislative history and policy to determine the legislative purpose. ${ }^{123}$ This section focuses on the role of policy in statutory interpretation.

Policy refers to the evils the statute attempts to eliminate or the problems the statute tries to solve. Ordinarily, courts will not interpret a statute contrary to its plain language in the name of policy. This is true for two mam reasons. First, courts should not lightly disturb statutory language because they should not be able to supplant the function of the legislature. If courts were able to use policy arguments freely, they would have too much freedom to rewrite statutes in the name of furthermg those statutes' goals. ${ }^{124}$ Second, even if the court knows the underlying policy goals of the statute, it is usually not im a position to say what course will best serve those goals. Courts often rely on administrative expertise for this determination, but an agency can be wrong. Agencies have organizational imterests that may conflict with statutory goals, such as an interest in making their jobs easier. ${ }^{125}$ Therefore, an agency's policy arguments should not ordinarily defeat clear language. ${ }^{26}$

On occasion, however, courts will consider policy even when the statutory language appears to be clear. ${ }^{127}$ Policy will prevail over the literal meaning of statutory language when strict adherence to it would lead "to absurd or futile results . . . [or] inerely an unreasonable one 'plainly at variance with the policy of the legislation as a whole.' "128

121. Brooklyn Nat'l Corp. v. Commissioner, 157 F.2d 450, 451 (2d Cir.) (L. Hand, J.), cert. denied, 329 U.S. 733 (1946) (terming statutory interpretation "the art of proliferating a purpose ... so that it shall be best realized upon the occasion in question").

122. Southeastern Community College v. Davis, 442 U.S. 397, 411 (1979).

123. Blue Chip Stamps v. Manor Drug Stores, 421 U.S. 723, 737, 748-49 (1975).

124. Hadden v. The Collector, 72 U.S. (5 Wall.) 107, 111-12 (1866) (Field, J.); see Callanan v. United States, 364 U.S. 587, 596 (1961).

125. See Associated Dry Goods, 449 U.S. at 603.

126. Binns v. Lawreuce, 53 U.S. (12 How.) 8, 17-18 (1851); 73 AM. JUR. 2D Statutes $§ 153$, at 358 (1974); see 62 Cases of Jam v. United States, 340 U.S. 593, 600-01 (1951) (courts are not free to modify a statute or otherwise add to or subtract fron it). A court inust follow a statute's plain language even if that interpretation requires the court to deny the statute legal effect. Yu Cong Eng v. Trinidad, 271 U.S. 500, 518-22 (1926). A fortiori, a court nust follow a statute's plain language even if that interpretation will reduce or eliminate the statute's practical effect.

127. United States v. American Trucking Ass'ns, 310 U.S. 534, 543-44 (1940).

128. Id. at 543. An example of policy prevailing over literal meaning is Sagansky v. United States, 358 F.2d 195, 201 (1st Cir.), cert. denied, 385 U.S. 816 (1966), where a criminal statute 
For similar reasons, policy considerations may prevail over indications of meaning from the legislative history. ${ }^{129}$ The next section discusses an established doctrinal framework which has been used at times as a vehicle for pohicy to override statutory language and legislative history.

\section{B. The Contemporaneous Construction Doctrine}

As Part III, Section B discussed, the contemporaneous construction doctrine grants extreme deference to an interpretation of a statute made by the agency charged with its enforcement and issucd contemporaneously with the statute's enactment. ${ }^{130}$ There are three reasons for giving deference to contemporaneous constructions. First, the administrative agency charged with enforcing the statute is presumably an expert in the field, so its imterpretations will be those most likely to accomplish the legislative purpose. ${ }^{131}$ Second, the quest for the proper construction of a law involves not only ascertaining the law's underlying objective but also achieving a practical administrative result, ${ }^{132}$ a job which the agency is best placed to accomphish. Finally, even if the

prohibited the interstate transmission "of bets or wagers . . . on any sporting event or contest" by anyone engaged in the business of betting or wagering. The Government alleged in each count of its indictment that Sagansky transmitted only one such bet, not "bets", but Sagansky's conviction was nevertheless affirmed on appeal. Another example is in United States v. Kirby, 74 U.S. (7 Wall.) 482 (1869) (Field, J.), where a statute prohibited "knowingly and willfully obstruct[ing] or retard[ing] the passage of unail, or . . . any driver, or carrier." Kirby was a Kentucky sheriff who arrested a postman for murder pursuant to a bench warrant. The Supreine Court held that the statute did not apply to the sheriff, despite his literal "obstruct[ing] . . . [a] driver."

129. See National R.R. Passenger Corp. v. National Ass'n of R.R. Passengers, 414 U.S. 453, 458 (1974) (dictum); Griggs v. Duke Power Co., 401 U.S. 424, 433-36 (1971) (an EEOC interpretation will be upheld if it can be reconciled with Title VII's language and history, despite some legislative history apparently cutting against the interpretation).

130. Norwegian Nitrogen Prods. Co. v. United States, 288 U.S. 294, 315 (1933) (Cardozo, J.). At the very least, the court uses the conteinporaneous construction rule to buttress its decision when it is persuaded that the agency's statutory coustruction is reasonably correct, while it distinguishes the rule away when it feels the interpretation is wrong. $2 \mathrm{~K}$. DAvis, Administrative LaW Treatise § 7:14 (1979 \& Supp. 1982); Kelso \& Kelso, Appeals in Federal Courts by Prosecuting Entities Other Than the United States: The Plain Meaning Rule Revisited, 33 HASTINos L.J. 187,199 (1981) (arguing that the use of canons of statutory construction is "unprincipled"). When a court is less certain as to the correct statutory construction, conteinporaneousness and consistency of interpretation (or the lack thereof) can certainly tip the scales. 2 AM. JUR. 2D Administra. tive Law §§ 241, 249 (1962); Annot., 39 L. Ed. 2d 942, 965-70 (1975). Furthermore, there is support for the proposition that a conteinporaneous construction can be "decisive," Skidmore v. Swift \& Co., 323 U.S. 134, 140 (1944) (dictum), or "determining," United States v. Erie R.R., 236 U.S. 259, 270 (1915) (dictum), or one which "will not be overruled except for weighty reasons." Fawcus Machine Co. v. United States, 282 U.S. 375, 378 (1931).

131. NLRB v. Medo Photo Supply Corp., 135 F.2d 279, 281 (2d Cir. 1943), affd, 321 U.S. 678 (1944).

132. SEC v. Texas Gulf Sulphur Co., 401 F.2d 833, 860-61 (2d Cir. 1968) (en banc), cert. denied, 394 U.S. 976 (1969); Thompson v. IDS Life Ins. Co., 274 Or. 649, 654, 549 P.2d 510, 512 (1976); accord Motor \& Equip. Mfrs. Ass'n v. EPA, 627 F.2d 1095, 1107-08 (D.C. Cir. 1979), cert. denied, 446 U.S. 952 (1980). 
agency's interpretation is not the optimally effective one, it is at least made at a time when no one could have relied to his detriment on a contrary interpretation. ${ }^{133}$

As Section A demonstrated, however, sucl policy reasons are not usually sufficient to justify an interpretation of a statute that is at variance with legislative history and statutory language: There are special reasons of reliability, lowever, that justify the extreme deference given to contemporaneous constructions. First, a conteinporaneous construction is normally the formulation of an entire administrative system, or, where it is in response to a statutory ainendinent, a reformulation of at least the parts of that systein affected by the ainendment. In contrast, a midstream change to an existing administrative systein is likely to affect only a few sections, and could very well represent a trial balloon or a stopgap ineasure. Hence, it is generally safe to say tliat a conteinporaneous construction is the product of more tliorough agency consideration; this thoroughness lends credibility to the construction. ${ }^{134}$ Second, there is an inference of reliability that can be drawn from consistent practice, and courts hesitate to overturn a construction that lias been consistently followed and relied upon from the beginning. ${ }^{135}$ Third, the contemporaneous construction doctrine gives judges little freedoin to pick and choose which practices are justified as furthering the statute's goals. Judges inay only use the doctrine to approve practices adopted contemporaneously with the statute's enactment and followed since.

\section{A Proposed Neocontemporaneous Construction Doctrine}

These same considerations favor deference to anotler sort of agency interpretation. Occasionally, an agency has failed to function properly since its creation. Then, perlıaps under new leadership, it completely overliauls its administration of its authorizing statute. This overhaul sparks a "rebirth," and the agency finally begins to function effectively. This new construction might be called a "neocontemporaneous" construction. This Note proposes that courts apply a "neoconteinporaneous construction doctrime," granting deference to a reborn agency's consistently followed statutory interpretations whicl1

133. See The "City of Panama," 101 U.S. 453, 461 (1879); Chee Lee v. Superior Court, 81 Ariz. 142, 147, 302 P.2d 529, 533 (1956); cf. United States v. Leslie Salt Co., 350 U.S. 383, 396 (1956) (agency is not free to clange a long-standing interpretation of a statute). In any case, the agency's interpretation will probably be nore efficient in practical terms than one conjured up by appellate counsel. See United States v. General Motors Corp., 518 F.2d 420, 437 (D.C. Cir. 1975).

134. Skidınore v. Swift \& Co., 323 U.S. 134, 140 (1944); Paden v. United States Dep't of Labor, 562 F.2d 470, 473 (7th Cir. 1977).

135. Mitchell v. Commissioner, 300 F.2d 533, 537 (4th Cir. 1962); see supra text accompanying notes 90, 133; see infra text accompanying note 140. 
lie within the "strained but not impossible" zone of statutory construction. This doctrine is supported by the same factors affording peculiar reliability to a contemporaneous construction.

First, such an interpretation of a statute is truly the one first "settimg its machinery in motion." The interpretation is issued by the enforcing agency, which is now even more of an expert on the subject since it has experience to learn from. ${ }^{136}$ Moreover, the thoroughness of the agency's consideration is evident from the fact that its procedures were completely overhauled instead of merely bandaged. ${ }^{137}$ Fimally, simce the agency is now functioning effectively, there is no doubt that a practical administrative result has been achieved. ${ }^{138}$

Second, a neocontemporaneous construction, just as a contemporaneous construction, limits the ability of judges to pick and choose. The neocontemporaneous construction occurs only once, and judges must take it or leave it when it occurs. ${ }^{139}$ Judges cannot lie in wait to uphold their favorite practice whenever it comes along.

Fimally, a neocontemporaneous construction, like a contemporaneous construction, does not disappoint legitimate reliance on past practice. Although many people rely upon a consistent and long-standing administrative practice, ${ }^{140}$ one is not entitled to rely upon erroneous

136. See supra note 131 and accompanying text.

137. See supra note 134 and accompanying text.

138. See supra note 132 and accompanying text.

139. Because the neocontemporaneous construction only happens once, it arguably does not reach two instances in which extreme deference to agency interpretations may be warranted. The first is where rapidly changing circumstances necessitate frequent adjustments to agency practice in order to conform to the times. The second is where the agency slowly evolves a satisfactory administrative system by repeated and frequent tinkering instead of violently overhauling its procedures. There is probably no need for the neocontemporaneous construction doetrine to apply to either.

The first scenario presents no problem because courts are already more willing to uphold an agency's actions in areas subject to constant change, see CBS v. Democratic Nat'1 Comm., 412 U.S. 94, 102-03 (1973) (involving a first amendment challenge to agency practice), as opposed to relatively static areas in which courts will disfavor new agency practices as against prior, longstanding ones, United States v. Leshe Salt Co., 350 U.S. 383, 396 (1956). Moreover, it is conceivable that Congress would give agencies freer rein in areas highly susceptible to changing conditions.

The second situation, on the other hand, does not warrant extreme deference. An agency that has been able to evolve a satisfactory administrative system contrary to statute through a series of small midstream changes arguably would be unable to show the thoroughness in consideration evident in contemporaneous constructions. See supra text accompanymg note 134. Furthermore, administrative convemence im itself is no reason to ride roughshod over statutory language, Assoctated Dry Goods, 449 U.S. at 603; a siguificant midstream departure fron statutory language and history should only be tolerated if the agency truly beheved that the departure was the only remaining way to save itself froin failure.

140. Considerations of simple fairness require that the agency be unable freely to alter such a practice. Thompson v. East Baton Rouge Parish School Bd., 303 So. 2 d 855, 857 (La. Ct. App. 1974); see United States v. Leslie Salt Co., 350 U.S. 383, 396-97 (1956). Furthermore, the legisla- 
administrative interpretations. ${ }^{141}$ Similarly, then, one should not be able to bank on a statutory interpretation which the enforcing agency is unable to implement effectively.

One caveat must be borne in mind, however. Not every practice adopted contemporaneously with a statute's enactment is entitled to deference, only those which serve the administrative need and convenience. ${ }^{142}$ The same should hold true for ncocontemporaneous construction. Normally, the adoption of a particular practice as part of the administrative system which precipitated an agency's rebirth is sufficient to raise an inference that the practice is an imstrumental part of the system. Raising the infercnce to a conclusion, however, would give the agency too much freedom to include new practices in its reform which had little or nothing to do with the nceded overhaul. Thus, the neocontemporaneous construction doctrine should not cover practices which, although adopted at the time of the overhaul, are so unrelated to the agency's revised mode of operation that no rational connection can be found between the practice in question and the inprovements brought about by the overhaul. ${ }^{143}$

Summing up the preceding discussion, extreme deference should be granted to agency practices inceting three requiremcnts: first, that there has been a failure of agency performance followed by a functionally successful rebirth; second, that the particular practice can be rationally connected with the functional improvements brought about by the rebirth; and third, that the particular practice is justifiable by a "strained but not impossible" interpretation of the agency's organic statute. This deference should be granted because such "ncocontemporaneous constructions" exhibit characteristics affording those interpretations particular rehability which are similar to those found in contemporaneous constructions.

\section{$\mathrm{V}$ \\ The Neocontemporaneous Construction Doctrine APPLIED TO THE EEOC}

Before 1977, the EEOC's administrative systein was unable to cope with the demands placed upon it. In 1977, the EEOC overhauled

ture could very well have rehed on the administrative interpretation in refusing to amend the statute. NLRB v. Bell Aerospace Co., 416 U.S. 267, 274-75 (1974).

141. In re Gcorge, 90 Wash. 2d 90, 97-98, 579 P.2d 354, 358 (1978); see Coca-Cola Co. v. Atchison, T. \& S.F. Ry., 608 F.2d 213, 222 (5th Cir. 1979).

142. See Estate of Sanford v. Commissioner, 308 U.S. 39, 53 (1939) (Stone, J.).

143. It makes no difference to the neoconteinporaneous construction doctrine whether the practice in question is a continuation or prior procedure. After all, one gear in a faulty machine could be taken out and placed in a device that works, and the gear may be nonetheless essential to the new machine's functioning. 
its procedures and the agency's performance dramatically improved. As part of that overhaul, the EEOC adopted several practices which strain the language of Title VII. The overhaul adopted the practice challenged in Associated Dry Goods; other aspects of the overhaul produced new procedures. ${ }^{144}$ This section will argue that the neocontemporaneous construction doctrime justifies these procedures. Sections $A$ and B explain the old and new EEOC system of operation to show that the EEOC in fact experienced a "functionally successful rebirth." Part C examines certain of the EEOC's new procedures and evaluates the apphicability of the neocontemporaneous construction doctrime to each. These evaluations exemplify the type of analysis which must be employed in order to apply the neocontemporaneous construction doctrine to the EEOC or any other agency.

\section{A. The Old Regime}

\section{The Procedures}

When the fledgling EEOC first opened its doors in 1965, the procedures it adopted ${ }^{145}$ created an administrative system which processed charges in the following manner.

\section{a. Intake}

First, the Commission received infornation from anyone claiming to be a victim of einployment discrimination, and then rendered assistance to that person in framing a charge if the information suggested that one could be brought. ${ }^{146}$ The intake of charges was generally handled by clerical staff who instructed a prospective complainant on how to fill out an EEOC charge form and then put the completed form in a holding file to be picked up by the next available investigator. ${ }^{147}$ As a consequence, the incoinplete, frivolous, or nonjurisdictional charges, which never should have been accepted in the first place but nonetheless constituted twenty percent of the EEOC's workload, ${ }^{148}$ were not disposed of until they had been pending for solne time.

\section{b. Deferral}

According to section 706(c) of Title VII, the EEOC must defer to state and local agencies enforcing local antidiscrimmation law. If a complaimt could be handled by such an agency, the EEOC must give it

\footnotetext{
144. See supra note 143.

145. 30 Fed. Reg. 8407 (1965) (codified at 29 C.F.R. $\S \S 1601.1-33$ (1966)).

146. 29 C.F.R. \& 1601.5 (1966).

147. See Volume V, supra note 107 , at 513-14 \& n.1562.

148. See supra note 109.
} 
sixty days to act before processing the coinplaint. ${ }^{149}$ Therefore, if a person walked into the EEOC with a coinplaint that could be handled by a state agency, the Commission would not accept the charge but would instead refer the person to the state agency. ${ }^{150}$ Unfortunately, a substantial portion of all charges referred in this way caine back, untouched, sixty days later. In fiscal 1974, the EEOC deferred 32,173 charges to state and local agencies; only about 7000 , or roughly two out of every nine, were processed by those agencies. ${ }^{151}$ Furthermore, the majority of such agencies did not process these charges adequately, often because they were saddled with workload probleins as well. ${ }^{152}$

\section{c. Investigation}

Once the charge was accepted for filing and picked up by an investigator, the investigator would solicit either a statement of the respondent's position ${ }^{153}$ or the respondent's response to written interrogatories. ${ }^{154}$ If not all facts were undisputed, the investigator would inake up a plan to gather relevant evidence and then set it into action. ${ }^{155}$ Investigators had virtually unlimited discretion whether to limit their investigations to the specific allegations in the charge or to look into "all like and related issues," generally necessitating a total review of the respondent's employment practices. ${ }^{156}$ In practice, the typical imvestigator disposed of two cases per inonth. ${ }^{157}$ It is no wonder that the investigation turned out to be the inajor bottleneck in EEOC charge processing. ${ }^{158}$

After the investigation had been completed, assuming that the charge had not been "administratively closed" prior to that time, ${ }^{159}$ the Commission would either dismiss the charge for lack of reasonable

149. 42 U.S.C. § 2000e-5(c) (1976).

150. 29 C.F.R. $\& 1601.12(1966)$.

151. Hill, The Equal Employment Opportunity Acts of 1964 and 1972: A Critical Analysis of the Legislative History and Administration of the Law, 2 INDUS. REL. L.J. 1, 71 (1977).

152. Id at 71-72.

153. 29 C.F.R. \& 1601.14 (1966).

154. Volume V, supra note 107, at 515.

155. Id.

156. Id at 515-16; telephone interview with Eleanor Holmes Norton, former Chair of the EEOC (Mar. 15, 1982). Respondents-with some justification-tended to characterize the latter type of investigations as "incessant fishing expeditions." See Oversight Hearing on Equal Employment Opportunities: Hearing Before the Subcomm. on Employment Opportunities of the House Comm. on Education and Labor, 95th Cong., 1st Sess. 51 (1977) (testimony of Eleanor Holmes Norton); VolUme V, supra note 107, at 531, 535 n.1610.

157. VOLUMe V, supra note 107 , at 531.

158. 1976 OVERSIGHT REPORT, supra note 105, at 31.

159. There was a high rate of "administrative closure," or dismissal without relief, 1976 OVERSIGHT REPORT, supra note 105, at 26, which sometimes meant that a case would be dismissed for failure to locate the charging party when in fact only one attempt had been made to contact that party. Staff of House Comm. on Education and Labor, 94th Cong., 2D Sess., 
cause $^{160}$ or issue a cause determination and then attempt to conciliate the parties. ${ }^{161}$ When no conciliation was reached in a case and the file was referred to the EEOC's regional litigation centers or its General Counsel, those offices, which either rejected the cases or recommended to the Commissioners that suit be filed, rejected between eighty and ninety percent of all cases, ${ }^{162}$ sometimes sending the cases back for further investigation. ${ }^{163}$ According to the Civil Rights Commission, these practices led to considerable strife within the EEOC. ${ }^{164}$

\section{The Results}

A few years after its inception, it became apparent that the EEOC could not handle its workload. Charges came $\mathrm{m}$ at a faster rate than they were resolved, and the inventory of outstanding charges swelled. ${ }^{165}$ In the early 1970 's, many charging parties were forced to wait two or three years before EEOC conciliated their charges. ${ }^{166}$ Congress was not satisfied with these results, ${ }^{167}$ and it accordingly amended Title VII in 1972. The EEOC also changed its procedures to allow Commission personnel to enter into settleinent negotiations with respondents prior to the issuance of a reasonable cause determination. ${ }^{168}$ But the EEOC was only able to slow the backlog's growth. ${ }^{169}$

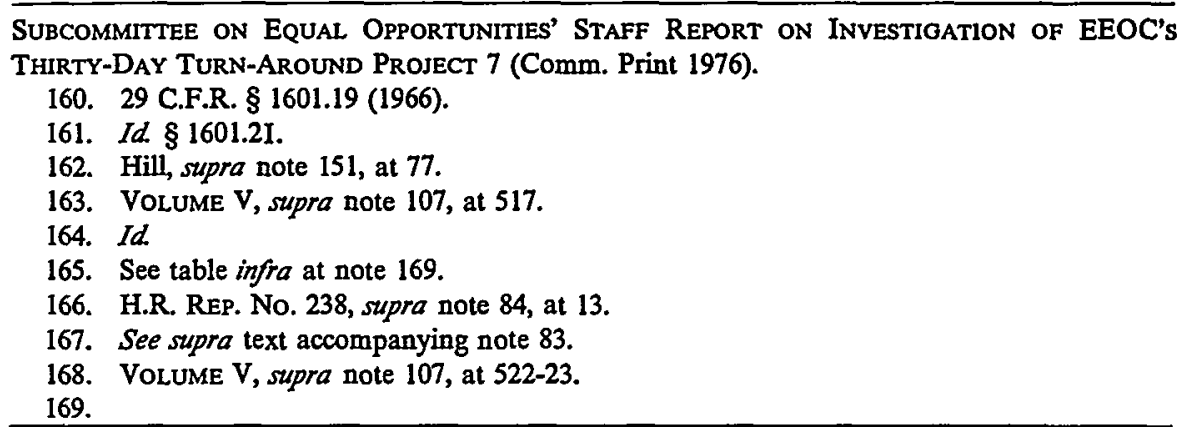

\begin{tabular}{lcccc}
\hline \multicolumn{5}{c}{ Average Compound Growth Rate Per Annum for the EEOC } \\
\hline $\begin{array}{l}\text { Fiscal } \\
\text { Years }\end{array}$ & $\begin{array}{c}\text { Charges } \\
\text { Received }\end{array}$ & $\begin{array}{c}\text { Charges } \\
\text { Resolved }\end{array}$ & Backlog & Appropriations \\
\hline $1966-1976$ & $28.0 \%$ & $29.5 \%$ & $47.0 \%$ & $35.1 \%$ \\
$1966-1972$ & 24.1 & 15.4 & 60.7 & 37.1 \\
$1972-1976$ & 21.9 & 47.6 & 23.5 & 29.8
\end{tabular}

Source: 1976 OVERSIGHT REPORT, supra note 105, at 26. Figures take into account both EEOC and deferral agency action. Numbers in the table were determined by log-linear regression. Coefficients of determination $\left(R^{2}\right)$ for the various models were as follows:

\begin{tabular}{lccccc}
\hline \multicolumn{5}{c}{ Coefficient of Determination of the Models } \\
\hline $\begin{array}{l}\text { Fiscal } \\
\text { Years }\end{array}$ & $\begin{array}{c}\text { Degrees of } \\
\text { Freedom }\end{array}$ & $\begin{array}{c}\text { Charges } \\
\text { Received }\end{array}$ & $\begin{array}{c}\text { Charges } \\
\text { Resolved }\end{array}$ & Backlog & Appropriations \\
\hline $1966-1976$ & 10 & 0.96 & 0.90 & 0.96 & 0.99 \\
$1966-1972$ & 6 & 0.89 & 0.82 & 0.97 & 0.99 \\
$1972-1976$ & 4 & 0.95 & 0.90 & 0.92 & 0.98
\end{tabular}


Although the EEOC's performance improved somewhat as a result of the 1972 changes, its performance was still inadequate. Charging parties were still forced to wait a median time of thirty-two months from filing to final disposition of their charge; ${ }^{170}$ even then, the EEOC was only successful at conciliating one charge out of every four im 1973 and less than one out of three in 1975. ${ }^{171}$ By the middle of 1976, tales of the EEOC's problems had attracted a great deal of attention. ${ }^{172}$ It was apparent that something had to be done to improve the situation; there was strong political pressure for change, either by congressional act, as had happencd in 1972, or by action of the agency itself.

\section{B. The 1977 Overhaul}

\section{Procedures}

Former EEOC chairman Clifford L. Alexander, Jr. maintained in 1976 that the end of the tunnel would not be seen until Congress granted the EEOC cease-and-desist enforcement power. ${ }^{173}$ Eleanor Holmes Norton, however, had a different idea which she put into action immediately upon accession to the EEOC chair in 1977. At the heart of the Norton reforms was a new charge processing systein. As discussed im Section $C$, this system contains several features which appear inconsistent with the language of Title VII. The remainder of this Section outlincs the new system.

\section{a. Intake}

Under the Norton reforms, professional staff perform preliminary screening on telephone inquiries ${ }^{174}$ and conduct initial interviews with charging parties to define the issues raised in charges even before they are accepted by the EEOC. ${ }^{175}$ One object of the screening and interview at the mtake level is to weed out frivolous or nonjurisdictional charges before they are filed. ${ }^{176}$ The Agency requires a charging party, on pain of charge dismissal, to submit a particularized statement of the harms he suffered and the respondent's actions which allegedly gave

170. Volume V, supra note 107 , at 529 . Note that Title VII provides that charging parties may demand a right-to-sue letter from the Commission after their charges have aged 180 days. 42 U.S.C. $\$ 2000 \mathrm{e}-5(\mathrm{f})(1)(1976)$. The statute seems to make the right-to-sue letter issue automatically, but in practice the EEOC waits for the party to request it. VOLUME V, supra note 107, at 519.

171. 1977 ClVIL Rights Report, supra note 108, at 197.

172. Alexander, supra note 113 , at 61 .

173. Id. at 66 .

174. 1981 EEOC COMPL. MAN. (CCH) $\S 1.4(a)$.

175. Id. \& 2.1(e).

176. 1977 CIVIL RIGHTS REPORT, supra note 108, at 214 . If a charging party insists on filing an invalid charge, however, the EEOC will accept it. 1981 EEOC COMPL. MAN. (CCH) $\$ 2.6$. 
rise to those harms. ${ }^{177}$ The Commission reserves the right to dismiss a charge after thirty days for failure of a charging party to cooperate with the investigation" ${ }^{178}$ or to accept a settleinent offer "afford[ing] full relief." 179

\section{b. Deferral}

If state and local agencies have the right to exclusive jurisdiction of a discrmination charge under section 706(c) of Title VII, the EEOC still defers such cliarges to those agencies. ${ }^{180}$ However, the EEOC will accept waivers of exclusive jurisdiction from tliose agencies, ${ }^{181}$ eitler on a charge-by-charge basis, or by blanket agreement. ${ }^{182}$ In the latter instance, the EEOC attempts to enter into what it calls "work sharing agreements" with state and local agencies. ${ }^{183}$ Under those agreements, the state agency in effect declares im advance the number of charges it can liandle, perhaps a given number within a set time interval or all charges filed against certaim designated respondents. The EEOC then assumes jurisdiction over the excess immediately, without waiting the statutory sixty-day deferral period. ${ }^{184}$

\section{c. Investigation}

The most drastic and innovative 1977 changes in EEOC procedures affected the charge imvestigation process. The heart of the EEOC's mvestigation is now the factfinding conference, which is "primarily an imvestigative forum intended to define the issues, to determine which elements are undisputed, to resolve those issues that can be resolved and to ascertaim whether there is a basis for negotiated settlement of the charge."185 The purpose of the conference is to flush out facts needed either to determine the merits of a charge or to achieve an

177. 29 C.F.R. $\$ \$ 1601.15($ b), . 19(c) (1981) (originally promulgated in 42 Fed. Reg. 47,828 , 47,834-35 (1977), and codified at 29 C.F.R. $\$ \$ 1601.15(\mathrm{~b}), .19$ (c) (1978)).

178. Id. $\S 1601.19$ (c) (originally promulgated in 42 Fed. Reg. 47,828, 47,835 (1977), and codified at 29 C.F.R. $\$ 1601.19$ (c) (1978)).

179. Id. $\S 1601.19$ (e) (originally promulgated in 42 Fed. Reg. 47,828, 47,835 (1977), and codified at 29 C.F.R. $\$ 1601.19$ (e) (1978)).

180. Id. $\$ 1601.13(\mathrm{a})(4)$ (i), (ii) (originally promulgated in 42 Fed. Reg. 47,828, 47,833 (1977), and codified at 29 C.F.R. $\$ 1601.13(\mathrm{c})(1),(2)(1978)$ ).

181. Id. $\$ 1601.13$ (a)(4)(iii) (originally promulgated in 42 Fed. Reg. 47,828, 47,833 (1977), and codified at 29 C.F.R. \& 1601.13(c)(3) (1978)).

182. Id. $\S 1601.13$ (c) (originally promulgated in 42 Fed. Reg. 47,828, 47,834 (1977), and codified at 29 C.F.R. $\$ 1601.13$ (e) (1978)); 1977 CIVIL RIGHTS REPORT, supra note 108, at 240.

183. 1981 EEOC COMPL. MAN. (CCH) \& 5.1.

184. 29 C.F.R. $\& 1601.13$ (a)(5)(ii)(A) (1981) (originally promulgated in 42 Fed. Reg. 47,828, 47,833 (1977), and codified at 29 C.F.R. $\$ 1601.13$ (d)(2)(i) (1978)); 1977 CiviL RIGHTS REPORT, supra note 108 , at 240 .

185. 29 C.F.R. $\$ 1601.15$ (c) (1981) (originally promulgated in 42 Fed. Reg. 47,828, 47,834 (1977), and codified at 29 C.F.R. $\$ 1601.15$ (c) (1978)). 
equitable settlement. ${ }^{186}$

The conference brings together the charging party and a representative of the respondent at a designated time and place, usually at an EEOC office. ${ }^{187}$ An EEOC professional is present to conduct the conference, and an EEOC note taker is there to record everything. The ground rules are simple. The parties go through each allegation of the charge. The charging party is allowed to explain and support his position, and then the respondent is allowed to defend, both without interruption from the other side; any questions are to be addressed to the EEOC official. ${ }^{188}$ At any time, either party or the mediator may call a recess in the conference if he wishes to talk about a settlement. ${ }^{189}$ Through this process, the parties either resolve each inatter of factual dispute or agree on the evidence necessary to resolve it. ${ }^{190}$

With the adoption of a new investigative system einphasizing rapid settlement of charges, the EEOC also clarified its prelitigation disclosure policy. It allowed cliarging parties to view whatever information the EEOC has on file about the respondent so they could fairly assess their chances of winning a court suit against the respondent. In addition to disclosure of inaterial its investigators had unearthed (the practice with which this Note has been primarily concerned), the EEOC also permitted disclosure of the factual circumstances of other charges involving the same respondent, provided the charges are "relevant and material" to the charging party's case. ${ }^{191}$

\section{The Results}

After the 1977 procedural overhaul, the EEOC's perforinance improved dramatically. When the systein was pliased in to all offices, in-

186. 1981 EEOC COMPL. MAN. (CCH) \& 14.2. For a more detailed description of the entire investigation process, see Note, The Use of EEOC Investigative Files in Title VII Actions, 61 B.U.L. REV. 1245, 1246-50 (1981).

187. 1981 EEOC COMPL. MAN. (CCH) \& 14.5(e).

188. See id. \& 14.7(b)(3) \& Exhibit 14-D.

189. Id. $\S 14.7(\mathrm{~d})$.

190. Id. $\$ 14.7$ (c). This technique had been used with considerable success at the New York City Commission on Human Rights, which Eleanor Hohnes Norton headed before her appointment to the EEOC chair. 1977 CIVIL RIGHTS REPORT, supra note 108, at 218-19.

191. 1981 EEOC COMPL. MAN. (CCH) \& 83.7(c)(1). The EEOC terms information in other case files "relevant or material" when the files

contain charges, investigations or determinations involving the same basis (e.g. sex, national origin, race) with limited exceptions such as when the private litigant's case alleged discrimination in promotion against females and the other case file involved a male's claim that he was not hired [because of his hair length]. Other case files may be relevant or material if they involve a different basis only when the treatment afforded one protected class is probative of treatment afforded the private litigant's class (e.g. systemic discrimination against Spanish Surnamed Americans is often probative as to treatment accorded Blacks and vice versa).

Id. $\$ 83.7$ (c)(2). 
take of nonjurisdictional and other charges inappropriate for EEOC processing fell $31 \%,{ }^{192}$ and the percentage of charges adıninistratively closed fell sharply. ${ }^{193}$ The average settleinent rate for all charges rose to nearly $50 \%$ from $14 \%$, the time lag in charge resolution dropped from two years to two months, and the total charge backlog dropped from 100,000 at the beginning of fiscal 1978 to 54,800 as of Septeinber $30,1979.194$

\section{Evaluating Particular Practices}

This section examines four particular practices out of the many adopted by the EEOC as part of its 1977 procedural overhaul. As parts $A$ and $B$ above have shown, the 1977 overhaul did in fact lead to a functionally successful rebirth, the first element of the neocontemporaneous construction doctrine. This section, therefore, analyzes the practices im light of the two remaining elements of the doctrine: that the practice is rationally coimected with the functional improvements brought about by the rebirth, and that the practice is justified by a "strained but not impossible" interpretation of the authorizing statute.

The first practice to be considered, the one with which this Note has been primarily concerned, is prehtigation disclosure of investigative information. Prior sections of this Note have demonstrated that the prelitigation disclosure rules can be supported by a strained but not impossible construction of the statute. ${ }^{195}$ Furthernore, as discussed in Section B above, the disclosure rules are rationally connected to the EEOC's dramatic reduction of its charge processing time because the new procedures emphasize settlement; ${ }^{196}$ this practice easily satisfies the requirements of the neocontemporaneous construction doctrine.

The second practice to be examined is interfile disclosure of

192. Departments of State, Justice, and Commerce, the Judiciary, and Related Agencies Appro. priations for 1980: Hearings Before a Subcomm. of the House Comm. on Appropriations, 96th Cong., 1st Sess., pt. 6, at 132 (1979) (statement of Eleanor Holmes Norton).

193. In the three "model offices" at which the EEOC's new programs were first implemented, the percentage of all charges administratively closed dropped from $35 \%$ to $20 \%$ at the end of the offices' first year of operation. Oversight on Federal Enforcement of Equal Employment Opportunity Laws: Hearings Before the Subcomm. on Employment Opportunities of the House Comm. on Education and Labor, 95th Cong., 2d Sess. 30 (1978) (statement of Eleanor Holmes Norton).

194. Departments of State, Justice, and Commerce, the Judiciary, and Related Agencies Appropriations for 1981: Hearings Before a Subcomm. of the House Comm. on Appropriations, 96th Cong., 2d Sess., pt. 8, at 257 (1980) (statement of Eleanor Holmes Norton). The charge resolution time for all charges, imcluding those in the backlog, was four months. Departments of Commerce, Justice, and State, the Judiciary, and Related Agencies Appropriations for 1982: Hearings Before a Subcomm. of the House Comm on Appropriations, 97th Cong., 1st Sess., pt. 2, at 372-73 (1981) (statement of J. Clay Smith, Jr.).

195. See supra text accompanying notes 19-22.

196. See supra text accompanying note 186. 
charges involving a common respondent, a practice struck down by the Supreene Court in Associated Dry Goods. ${ }^{197}$ Although section 706(b) says that "charges shall not be made public," it is arguable that the "public" with respect to any respondent should not include anyone who had filed a charge against that respondent. This reading can be buttressed by Congress' emphasis on the private right of action in the Title VII enforcement scheine, ${ }^{198}$ for such an interpretation would encourage charging parties to file class actions, thereby allowing employees who had not filed charges to share in any judicial rehef. ${ }^{199}$ The neoconteinporaneous construction doctrine, however, does not validate this practice because an essential element is not satisfied: the practice has no rational connection with the 1977 EEOC rebirth. Although interfile disclosure will give charging parties evidence with a potentially powerful clout in the courtroom, that evidence would not be relevant to the merits of their own claims. ${ }^{200}$ Such disclosure therefore does not seem to help a party to settle a claim, or otherwise to further Title VII's goals. Thus, interfile disclosure cannot be justified under the neocontemporaneous construction doctrine.

A third agency practice that was part of the 1977 EEOC overhaul is the factfinding conference. This implicates Title VII because any participant in the conference can call a recess at any time to discuss settlement, and one of the EEOC's inajor objectives in impleinenting the conference was to have cases settled during or after it. The conference, therefore, conceivably could be held a conciliation endeavor within the meaning of section 706(b) of Title VII. That section, however, arguably does not authorize the EEOC to conciliate until after it has completed the investigation and found reasonable cause. ${ }^{201}$ But the statute does not expressly forbid conciliation before the investigation is over. ${ }^{202}$ Furthermore, the EEOC has been settling charges prior to cause determination since $1972,{ }^{203}$ and Congress has never objected.

197. See supra note 17 .

198. See supra notes $103-04,110$ and accompanying text.

199. E.g., Oatis v. Crown Zellerbach Corp., 398 F.2d 496 (5th Cir. 1968).

200. Certainly, charging parties may benefit by knowing of other discrimination charges since they could be introduced in evidence to prove a pattern of discrimination. See FED. R. EviD. 406. However, other parties' charges, as opposed to "generally relevant information," see supra note 65 , are clearly irrelevant to the merits of a charging party's claim.

201. "If the Commission determines after such investigation that there is reasonable cause to believe that the charge is true, the Commission shall endeavor to [conciliate the charge.]" 42 U.S.C. $\$ 2000 \mathrm{e}-5(\mathrm{~b})$ (1976) (emplasis added). If EEOC finds that reasonable cause is lacking, it unust dismiss the charge. Id. EEOC's 1965 regulations also appear to support this position. 29 C.F.R. § 1601.21 (1966). This provision as a whole implies a two-step process: first, investigation leading to a reasonable cause determination, and then conciliation. Thus, any temporal mixing of these pliases could be invalid.

202. 42 U.S.C. $\$ 2000 \mathrm{e}-5$ (b) (1976).

203. VolUMe V, supra note 107 , at 522-23. 
Thus, the construction of Title VII called for by the factfinding conference is far from impossible, and the procedure, much more than being rationally related to the EEOC's new system, is one of its keystones. ${ }^{204}$ Thus, the neocontemporaneous construction doctrine supports the EEOC's establishment of the factfinding conference.

The final practice to be considered here is the EEOC's new deferral policy of accepting waivers of exclusive jurisdiction froin state and local agencies. This new policy raises the Title VII question of the ability of a state agency to make an effective waiver of its exclusive jurisdiction without forinally terminating its processing of a charge. ${ }^{205}$ It can be argued that a blanket waiver contained in a work sharing agreement might be contrary to Title VII while an individual waiver would not, since in the former instance the state agency may be induced to relinquish jurisdiction not because of the state agency's workload, which it would ouly be able to predict roughly, but because it receives federal money by being on the EEOC's good side. ${ }^{206}$ The Commission responded to public comment on that point by saying that the purpose of the deferral provisions in section 706(c) of Title VII was to give state agencies the chance to process charges before the EEOC steps in, and that waivers in general do not diminish the opportunity given to those agencies. ${ }^{207}$ After all, section $706(\mathrm{c})$ does not apply to proceedings under state or local law which "liave been earlier terininated," and the section puts no exphicit lid on low much earher, or by whom, the proceedings can be terminated. ${ }^{208}$ Thus, the deferral policy adopted by the EEOC is reconcilable with Title VII; it may require a strained construction, but not an impossible one. The rational relationship element is also met. Since state and federal enforcement was uncoordinated before $1977^{209}$ and the median charge resolution time afterward dropped to two months, ${ }^{210}$ the statutory deferral time, ${ }^{211}$ it seeins rational to conclude that the 1977 deferral policy is related to the improvements brouglit about by the 1977 overhaul. Thus, the neocontemporaneous construction doctrine supports the EEOC's new deferral policy.

204. See supra text accompanying notes $185-86$.

205. 42 Fed. Reg. $47,828,47,829$ (1977).

206. See 1981 EEOC COMPL. MAN. (CCH) § 5.1. In fiscal 1978, the EEOC's appropriation for funding state and local agencies was $\$ 10.4$ million, $13 \%$ of the agency's total budget for that year. 1977 Civil RIGHTS REPORT, supra note 108, at 240.

207. 42 Fed. Reg. 47,828, 47,829 (1977).

208. 42 U.S.C. $\$ 2000$ e-5(c) (1976).

209. See supra text accompanying notes 151-52.

210. See supra text accompanying note 194.

211. 42 U.S.C. $§ 2000 \mathrm{e}-5$ (c) (1976). 


\section{CONCLUSION}

The Supreme Court in Associated Dry Goods upheld the EEOC's prehitigation disclosure to charging parties of information relevant to a potential lawsuit, even though this practice could only be supported by a strained reading of Title VII. The Court advanced a number of reasons for its judgment, based on the statute itself, legislative history, the contemporaneous construction doctrine, and pohicy. All but the policy arguments are weak. The policy arguments, though sound enough in themselves, are not sufficient to override the plain ineaning of the statute. Not only was the Court's reasoning unpersuasive, but it left other innovative EEOC procedures vulnerable to similar challenges that they violate the statute-challenges apparently rebuttable only by similar tortured legal arguments and overreaching pohicy arguinents.

The practice upheld in Associated Dry Goods occurred before 1977. In its 1977 procedural overhaul, the EEOC continued this practice and adopted several others which, like the practice in Associated Dry Goods, can only be supported by a strained but not impossible statutory construction. This Note proposes an extension to the contemporaneous construction doctrime that accords deference to many of these practices. This neocontemporaneous construction doctrine extends the logic of according deference to agency constructions made at the time a statute is passed to agency constructions inade as part of an overhaul of a poorly functioning agency. Applying this doctrine, this Note argues that many of the practices adopted by the EEOC as part of the 1977 overhaul, including the practice challenged in Associated Dry Goods, should be upheld under the neocontemporaneous construction doctrine.

Thomas Yamachika*

* Sc. B. 1980, Yale University; second-year student, Boalt Hall School of Law, University of California, Berkeley. 